\title{
A case study on teacher training needs in the Madrid bilingual project $^{1}$
}

\section{Estudio sobre las necesidades de formación del profesorado del proyecto bilingüe de la Comunidad de Madrid}

\author{
Pilar Cabezuelo Gutiérrez \\ Centro Universitario Cardenal Cisneros \\ (Alcalá de Henares, Spain) \\ Raquel FERNÁNDEZ FERNÁNDEZ \\ Centro Universitario Cardenal Cisneros \\ (Alcalá de Henares, Spain)
}

\begin{abstract}
Bilingual education programs are gaining special prominence in non-English speaking countries as part of the necessary adaptation demanded by the White Paper on Education and Training (1995) in both educational and social fields, thus becoming a key element in any long-term academic planning. The present case study analyzes the opinion of 17 primary teachers in the Madrid bilingual program with regard to the language and methodological training received since its implementation ten years ago. The study also aims to gather feedback from the teachers in order to define potential opportunities for improvement in teacher training. This study stems from two previous studies conducted by Fernández Fernández, Pena Díaz, García Gómez, and Halbach (2005) and Fernández and Halbach (2011) as a basis of understanding how the teachers feel about their initial training, its application to real-life classes, and their current and future needs in this area. After carefully analyzing all of the results, it seems that the situation in teacher training has improved over the years. However, there is still much work to be done in order to make this project progress successfully. Key Words: language policy; in-service training; teacher attitudes; case studies; project evaluation.
\end{abstract}

\section{Resumen}

Los programas de educación bilingüe están ganando cada vez un mayor protagonismo en países de habla no inglesa como parte de la necesaria adaptación demandada por el Libro Blanco sobre la educación y la formación (1995) en el terreno educativo y social, convirtiéndose así en una pieza clave de los programas de formación académica. Este estudio analiza la opinión de 17 profesores de primaria de dicho programa sobre la formación lingüística y metodológica recibida desde su puesta en marcha hace diez años. El estudio también recoge comentarios y opiniones entre los profesores de cara a poder definir oportunidades de mejora para el programa en dicha área de formación y desarrollo del profesorado. Este estudio se basa en dos estudios anteriores realizados por Fernández, Pena, García and Halbach (2005), y Fernández y Halbach (2011) sobre como los profesores han ido valorando su preparación para el trabajo en el programa bilingüe, su aplicación en el día a día y sus necesidades de formación a futuro. Una revisión en detalle de los resultados desvela que, si bien la situación ha ido mejorando en los últimos años, aún queda bastante por hacer de cara a asegurar una mejora continua de este programa. Palabras Claves: política lingüística; formación en el empleo; las actitudes de los maestros; estudios de casos; evaluación de proyectos.

${ }^{1}$ The authors would like to thank James Crichlow (Centro Universitario Cardenal Cisneros) for contributing to the improvement of the original version of this article. 


\section{INTRODUCTION}

Nowadays, it is a fact that English is used as a language for International Communication for many aspects of our daily life, such as applying for a job, traveling, surfing the Internet, or studying a degree. In recent decades, European Institutions have actively promoted diversity and pluralism in language education. The Committee of Ministers Concerning Modern Languages established intercultural communication and plurilingualism as the main policy goals in the Recommendation No. R (98) 6. They also indicated a number of specific measures to be taken to target these objectives, namely: encouraging Europeans to achieve a degree of communicative ability in a number of languages, teaching programs at all levels using a flexible approach, the use of foreign languages in the teaching of non-linguistic subjects and the application of communication and information technologies to disseminate teaching, and learning materials for all European national and regional languages (see Council of Europe, 2006, p. 9).

As a result of the crucial importance of learning English, the CLIL approach is being used in order to improve bilingual education. As indicated by Figel (2006):

Content and Language Integrated Learning (CLIL) at school seeks to develop proficiency in both the non-language subject and the language in which this is taught, attaching the same importance to each. Furthermore, this approach aids to teach a non-language subject in a foreign language but with and through a foreign language. (p. 7)

It is essential thus to understand that CLIL does not solely concern language, but also content learning and its full integration. Using CLIL in the classroom is a challenge for teachers, and their needs and expectations have still not been thoroughly studied, as Laorden and Peñafiel (2010, pp. 325-326) point out. Furthermore, Pena and Porto (2008) mention the key role beliefs and conceptualizations made by teachers in the educational development of students involved in bilingual programs. In their words: "When it comes to bilingual teachers, their personal baggage, knowledge and concept of bilingualism is of vital importance.” (p. 153).

Due to this fact, it is of vital importance to study what teachers believe in order to be able to understand the way they teach. In addition, it is fundamental to study the needs of the teachers involved in the bilingual teaching projects 
carried out in a number of primary schools in the Autonomous Community of Madrid (Spain). This aspect is expected to help us to improve future training and provide information and feedback on the training they completed (Pena \& Porto, 2008, p. 151).

Taking into account all of the previous information, the main objective of this study is to reflect on CLIL teacher training in relation to the teachers working in the bilingual project launched in the Autonomous Community of Madrid since its implementation in September 2004. There are two research studies carried out by Fernández Fernández, Pena Díaz, García Gómez, and Halbach (2005) and Fernández and Halbach (2011) which clearly defined teachers' concerns, motivations and needs prior to and four years after the implementation of the program. Based on this research, there are a number of areas of concern and improvement as expressed by the professionals interviewed in the research phases of the aforementioned studies which are worth following up, since they are pertinent to the evolution and implementation of the plan in the Autonomous Community of Madrid. However, this study takes an in-depth look at two key areas:

- The training that the teachers have received so far, to verify whether the training needs that the teachers identified 3-4 years ago, in 2011, have been addressed. This aspect allows us to check the effectiveness of the training that teachers receive.

- The training that teachers would like to receive, which helps identify future lines for teacher training.

Unfortunately, there are still not enough studies to properly analyze these teachers' concerns. Fernández Fernández et al. (2005) were interested in finding out teachers' expectations before the project was implemented, but little research has been carried out to gain an understanding about the evolution of teacher training aspects within the bilingual program in the Autonomous Community of Madrid after nine years of implementation. It seems that the bilingual project remains more focused on the students' concerns and needs, whilst focusing less on the teachers' requirements. In this context, Laorden and Peñafiel (2010) carried out a study analyzing the perceptions and opinions of a group of Heads of Departments of Bilingual Schools in the program. The authors indicate that most Heads of Departments that took the survey support the project and believe it 
adds value for their schools. However, they indicate major needs among which high-quality teacher training stands as one of the most obvious.

Also in Madrid, but focusing on a different area, Johnson (2012) offers a valuable and innovative perspective analyzing the beliefs of university lecturers delivering content-subjects in English and through the CLIL approach in a teacher education college in Madrid. These university lecturers are in charge of training students who are expected to become pre-school and primary-school teachers. Many of them are expected to be working in the Madrid bilingual project in the future.

More recently, in 2010, the Madrid bilingual project was extended to secondary education. In their study, Olivares and Pena (2013) revised the language training that secondary teachers receive as part of the competences they need to achieve in order to deliver content-based subjects in English, and propose training models which may be considered to improve these programs, offered by universities and language institutions.

In general terms, the true basis and source of reference for the present study can be found in the research work conducted by Fernández and Halbach (2011), where a number of opportunities and concerns related to the needs of the teachers are highlighted. The teachers participating in the research highlighted two specific training needs in the two following areas: teaching reading and writing in English (66\%) and teaching science in English (62\%). In the short to medium term, teachers needed to improve: designing materials (43\%), methodology (30\%), locating resources (30\%). Finally, the areas where teachers needed less improvement were: foreign language (26\%), teaching arts and crafts (25\%), and use of computers (19\%). Another interesting point in the context of teachers' perceived training needs is the fact that quite a significant number of them $(26.8 \%)$ said that they needed to improve their language skills.

The main objective of the present study is to evaluate in-service teachers' needs and perceptions regarding the teacher training received as part of the staff involved in the bilingual project of the Autonomous Community of Madrid since its implementation in September 2004. This study is meant to be a continuation of the two research studies carried out by Fernández Fernández et al. (2005) and Fernández and Halbach (2011).

The key hypothesis formulated here is that training needs have evolved over the last 10 years and now focus on different areas from those addressed in 
previous decades. In addition, current training programs are not in line with these new teacher demands, regarding their teaching practice by collecting regular feedback from the professionals working in the program, and researchers and educational stakeholders who can make improvements to the original program, ultimately benefitting pupil's learning.

\section{METHOD}

\section{Participants and research context}

The geographical context in which this study has been conducted comprises both state-owned and state-financed schools in the Autonomous Community of Madrid. Regarding participants, 12 schools took part in this study voluntarily, with a total 17 in-service teachers who provided valid responses by means of an online questionnaire.

As the research context has particular characteristics which need to be taken into account to carry out the study, we describe its main features here. The Madrid bilingual project was launched in March 2004, when the Regional Government of Madrid issued a decree establishing a bilingual project in primary education. The number of schools (and students) participating in the project has, since then, been increasing steadily. According to the official website of the Ministry of Education of Madrid, approximately 120,000 students are currently under the Spanish-English bilingual program in Madrid. The majority of these students $(66,000)$ belong to state-owned bilingual schools.

Regarding teaching organization, the Madrid bilingual project indicates some general guidelines that all schools should follow. The first states that the subjects Spanish Language, Mathematics, and English are to be taught every day. Also, except for Spanish Language and Mathematics, the remaining subjects on the curriculum may be taught in English. Finally, at least a third of timetabled classes are to be taught in English. As regards the school timetable proposal by the Autonomous Community of Madrid, at bilingual primary schools, at least one third of the 25-hour schedule is to be taught in English, although this number can be greater than 50\%. Apart from Science, Cultural Studies, and Social Studies, any subject can be taught in English, except for 2, Spanish Language and Mathematics, which must be given in Spanish. 
It is also important to point out that the number of teachers receiving CLIL training has increased accordingly ( $240 \%$ over the last 5 years) reaching a total of 2,315 qualified professionals in 2013. Concerning the situation in the Community of Madrid, the bilingual teaching staff of bilingual schools is composed by inservice teachers who have been qualified to teach content through English via the so-called Habilitación Lingüística ("Linguistic Certification", our translation).

Primary teachers are content specialists unless they are EFL teachers. Their profile is teaching content using a foreign language, but they are not language specialists. However, there is a clear consistency gap regarding the evolution of the training structure and objectives for the teachers taking part in the program if we compare the initial requirements back in 2014 with the situation today.

From the start of the program in 2004 until 2009/2010, teachers were offered a formative schedule through an Initial Training Plan which provided them with the appropriate language qualifications required to work as a teacher within the Autonomous Community of Madrid program.

Teachers needed to pass a language level test to be able to take part in the training plan, to ensure that they would be able to benefit from the training courses. Besides, non-specialist teachers in English must have a B1 CEFRL (Common European Framework of Reference for Languages; see Council of Europe, 2001) competence level, while specialist English teachers must have a B2 level CEFRL level.

Based on the results from the above mentioned tests, teachers received 2 different types of training programs as follows:

1. Targeted at teachers with a B2 (CEFRL) level. These teachers received language training in an English-speaking country for 4 months.

2. Targeted at teachers with a B1 (CEFRL) level. The selected professionals receive training in the following 3 forms:

- $\quad$ Reinforcement training imparted locally by the British Council.

- $\quad$ Language training in an English-speaking country.

- $\quad$ An additional 30-hour course given by the Autonomous Community of Madrid about CLIL methodology.

Moreover, instruction in English throughout the year finally enabled teachers to obtain the appropriate qualifications and certificates. Those without a position in a bilingual primary school in the academic year following the initial training 
have three years to complete this final phase. All teachers trained and qualified in this way are required to commit to teaching in English within the program.

Approximately 1,800 teachers have been trained and qualified in the past through this process. This ensures that there are a sufficient number of qualified teachers and that all bilingual primary schools have the teachers required for the program to function under optimum conditions.

However, the situation in 2013 is rather different from the early days of the bilingual program. Currently, teachers can get the official qualification to teach through English by certifying a C1 CEFR level of English at the time they pass the state exams to access their teaching position. Furthermore, teachers receive all the reinforcement and language improvement through "virtual sessions" from an English training company based in South-West England. These are the socalled "Acacia Courses". These virtual courses are the only option currently offered to teachers as a replacement of the ambitious initial reinforcement and development training programs.

\section{Data gathering tool}

The information was gathered by sending out an online questionnaire designed to collect the information in a structured and organized way. The questionnaire used by Fernández and Halbach (2011) was taken as a reference to create the one used in this study. The questionnaire includes a section on general information, which deals with the personal details relevant to the study; questions regarding the training they had received prior to commencement of the project; the training they lack and the training they would like to reinforce; their perception and opinion regarding the training they have received parallel to the implementation of the project.

The questionnaires (see Appendix 1) were sent by e-mail to a selected group of 13 schools of the Madrid bilingual project.

\section{RESULTS}

In this section, the main findings are summarized and analyzed with respect to the 4 separate sections included in the questionnaire. 


\section{General information section}

Concerning the "General Information" section, all of the teachers who completed the questionnaire worked at schools in Madrid and were involved in the bilingual program. From the whole sample $(n=17)$, there were more teachers working at schools which had recently implemented the bilingual project between 2009 and 2012 (10) than at experienced schools which had implemented the project between 2004 and 2005 (7). Most of the teachers indicated that they had an advanced level of English (10), but some also affirmed having proficiency level (5) and in one specific case, an intermediate level.

\section{Prior training section}

The section devoted to the training received prior to commencement of the project comprised several questions. Regarding the first question ("Which courses have you attended in order to improve your initial English Language skills?”), only 1 teacher had not received any training for work in the bilingual program (she is native). Others had attended courses at the British Council (7), at British universities and institutions in United Kingdom/Ireland (4), or online (7).

In response to the second question in the prior training section ("Please select your field of specialization. Now indicate what course or courses you attended and where were they held in."), five of the respondents were science specialists, two were arts-and-crafts specialists, 1 was a physical education specialist, and all of them were English language teachers. Regarding the courses they attended, there was a considerable variety, from English courses held in English-speaking countries (Ireland, England, Scotland) to specific training locally in Spain or in English-speaking countries, such as a workshop on Jolly Phonics in Alcalá de Henares (Madrid, Spain), and on the use of ICT, and the development of speaking skills in the UK.

For the third question in the prior training section ("Did you receive other professional training apart from that mentioned above?"), from the possible options, most of the teachers indicated that they had received professional training related to the use of ICT and, in second position, methodology and design of materials training. However, to a lesser extent, teachers had also received training in the location of resources. 


\section{Lack of prior training section}

The section regarding training that they had not previously received (or that they would like to reinforce) began with the question, "Which courses would you like to receive in order to reinforce your English language skills?”. From the options offered, 11 out of the 17 participant teachers indicated that they would like to receive permanent English courses in the school where they were currently working. Also, 9 of them indicated that they would like to receive intensive courses at "English villages" in Spain. Furthermore, 8 participants indicated that they would choose English language courses overseas, and 7 indicated that they would like to take British Council and Official School of Languages courses. Online courses were by far the least preferred option, being chosen by just 3 participants.

With regards to the second question in this section, "In which of the following areas regarding your field of specialization would you like to receive further professional training today?", 2 of the areas proposed were chosen by the majority of participants. These were "classroom management and motivation", chosen by 13 participants; and "methodology", chosen by 12 teachers.

\section{Evaluation of teaching training section}

The last section concerned the teachers' evaluation of teaching training received so far to work as teachers in the bilingual project. In the first question ("In general, are you satisfied with the professional teaching training you have received so far?"), we received a higher percentage of negative responses (11, $\mathrm{n}=17$ ) than positive $(6, \mathrm{n}=17)$. Analyzing the second question ("The teaching training you have received in general is .... Please justify your previous answer.”), most of the teachers indicated that they believed the training they had received was sufficient (7), but needed improvement (6). There was also 1 teacher who stated that their training was insufficient, while 3 considered it adequate.

It is necessary to expand further upon the responses to this question, as it is of utmost importance to understand the teachers' final perception of their training. Moreover, we use the table with the responses gathered in the questionnaire (Appendix 2). Taking into account all of the justifications, we can clearly divide these into 2 different categories: concerns related to university studies, and concerns related to further teacher training. Regarding the first 
concern, there was 1 teacher $(n=17)$ who complained about that the focus of university studies was inappropriate for becoming a bilingual teacher: "I think the university studies are not adequate to the job" (c. 1), they stated.

With regard to the second concern, related to further training, the rest of the teachers highlighted a strong need for permanent training courses to keep up to date with the latest innovations in teaching techniques and methods in order to meet the current needs of their students:

I would like to attend more training courses in which I could learn new methods or techniques to be able to adapt myself to the current needs of my students. I think that it is very important that teachers keep studying to improve and renew their methods. (c. 2)

In the third question ("Are you receiving any further training today from the Administration? If you answered "yes" to the previous question, please indicate what course or courses and the Institution providing it."), all of the teachers except 3 had not received any further training to improve their knowledge within the bilingual project. With respect to the teachers receiving current training, the majority of the courses were online courses working with computing techniques. Many of these courses were provided by the "Acacias Institution".

Concerning the fourth question ("The teaching training you are receiving today is .... Please justify your previous answer.”), out of the small number of teachers that had recently received further training, most of them believed that this training was insufficient $(2, n=5)$ and that it needed improvement $(2, n=5)$, whereas only 1 teacher thought it was adequate. Regarding their justifications, they indicated that most of the courses should be more focused or centered on their daily routines and tasks.

Finally, in the last question ("Do you think your training [language level, methodological training, etc.] enables you to perform your role as a teacher well in the Project?"), 13 teachers believed that the training they had received allowed them to perform their work in the bilingual project, whereas only 4 believed that it did not. This result does not seem to run parallel with the previous answers, as $24 \%$ said that they were not satisfied with the training they had received so far, but $76 \%$ said the training was sufficient to carry out their work. This information is analyzed in detail later in the present paper. 
In general terms, the teachers' comments indicate the need for continuous training to carry out their work successfully and the inadequacy of teacher training degree programs to cope with the characteristics of these new teaching profiles.

\section{DISCUSSION}

As regards the bilingual project teaching staff, and having the participants of the study as the only reference, they can be considered a group of enthusiastic, hardworking professionals. Most teachers showed a clear interest in improving their level of English and program competencies, as is clearly reflected in the following response:

"I would like to attend more training courses in which I could learn new methods or techniques to be able to adapt myself to the current needs of my students. I think that it is very important that teachers keep studying to improve and renew their methods." (c. 4)

After eight years of implementation, some progress and specialization in the teacher training organized by the administration is expected. Nevertheless, it seems that the bilingual project has experienced very little progress regarding the teacher's demands on training and development of teaching skills. Quite the contrary, results show that teacher training has decreased dramatically.

There still seems to be a conflict regarding who is responsible for improving the level of English as well as the skills needed to teach. While almost everyone agrees about the need for a continuous training strategy, it is not clear whether this should be done within or outside of working hours. Some teachers manifest their personal interest in personal growth through their own initiatives, while others demand more support with official courses from the Autonomous Community of Madrid. In the questionnaire, the teachers indicated that they were currently receiving training from other institutions, such as computing courses offered by the ICM, an arts-and-crafts course offered by OUP in collaboration with the Autonomous Community of Madrid, and an online course offered by the Regional Centre of Innovation and Training (CRIF) Las Acacias concerned with Web 2.0 resources applied to foreign languages. It is disappointing to observe that only 3 bilingual teachers out of the 17 participating in the questionnaire were receiving further teacher training. However, this was not always meeting their needs, as can be gathered from the comments of some 
participants. Overall, it seems that the program is still far from having a mechanism in place to spread good ideas and practices.

With regard to Fernández's and Halbach's previous study (2011), some of the key conclusions reflected in their document are worth comparing and analyzing with the results of the present project to see how the situation has evolved over the last 5 years. One of the outstanding changes after this period of time is that the bilingual teachers no longer appear to be concerned about the required level of English to conduct their classes and to teach the contents but on the need to expand methodological capabilities. Sixty-six percent $(66 \%)$ of the teachers expressed their need of receiving further training in the areas of teaching, reading, and writing in English. Also, 26.8\% of them acknowledged that they needed to improve their language skills. In this study, however, only $35 \%$ of the interviewed teachers said that they would like to receive further language training as they wanted to improve and fine-tune the skills they already had.

This change in perception could have been driven by the availability of improvement courses provided to teachers over the years within this area and the availability of materials that have been provided to teachers in order to progress in these skills. These positive changes could have also been a result of gaining experience over the years. After five years, the teachers might have learned to improve their teaching of reading and writing skills, and also science, as a consequence of practicing and innovating new ideas with their students.

It seems that their initial concern about teaching in another language has also changed. Now, they somehow recognize that the challenge is teaching through CLIL, which is more than simply teaching in English and classroom management. As some influential authors say, CLIL is seen as a "flexible system which responds to a very wide range of situational and contextual demands" (Coyle, 2005, p. 23); it is an educational approach that integrates content and language, either by learning a content subject through the medium of a foreign language or learning a foreign language by studying a content-based subject (Tucker \& Earl Lambert, 1972; Genesee, 1987; Marsh, 2000).

Another interesting element that can be gathered from the present study, as compared with the previous study by Fernández and Halbach (2011), is that teaching science content no longer seems to be a concern for teachers, at least for those mentioned in the survey. Some $62.5 \%$ of the bilingual teachers in Fernández's and Halbach's study expressed their need for further training in 
teaching science in English. Nevertheless, none of the teachers contacted in the current study expressed a desire to receive further training on teaching CLIL contents. This is likely because these teachers have gained sufficient experience and because they already have access to good teaching materials.

However, there is one aspect upon which both groups of specialized teachers agreed. As Fernández and Halbach (2011) conclude, "the aspects more attributable to the educational administration receive higher ratings as constituting areas where change is necessary: Increasing training opportunities (60.7\%), with one teacher mentioning the need to improve the quality of training opportunities as well" (p.253). The same can be observed in the present study: only 1 teacher believed that the training was adequate, the rest of the teachers complained that it was sufficient or insufficient and that it needed further improvement with continuous training courses and opportunities.

Regarding this study's objective to provide information about the areas future teacher training should cover, it seems clear that an additional program for training and development for the teacher taking part in the program should be urgently put in place to ensure competitiveness of this program in relation to other European countries. In this regard, a benchmark study of the Madrid bilingual program against other European programs should be carried out to identify areas of improvement and to gather the best practices for teachers in similar situation.

In relation to the training areas indicated by the teachers participating in this study, it remains clear that they would be willing to be trained in methodology and classroom management. The need for adequate methodology in the bilingual classroom may be pointing out the lack of adequate and highquality CLIL training provided by the Administration.

Regarding professional development, some teachers participating in the study provided certain ideas that could be easily incorporated into the bilingual project structure. Namely, they mentioned that there is a need to create a standardization strategy to leverage all the materials created by all teachers working in the program of the Autonomous Community of Madrid (or similar initiatives elsewhere in Spain). This would reduce the amount of time devoted to prepare their materials for the classes. The second idea concerned the creation of discussion forums (virtual) to share experiences, ideas, concerns, and other information. 
The present study clearly reveals the need to continue conducting more research in this area to provide ideas and initiatives to strengthen the bilingual program in the Autonomous Community of Madrid. As a possibilities for future study, 2 areas of improvement are suggested to build on this case study:

1. The situation of the training programs for teachers initially designed for the program and the situation today. It is of key importance to understand what has happened and the necessary improvements, corrections and adaptations to be done in order to keep teachers in line with the necessary competency standards required for the success of the program.

2. The need to update teachers currently working in the program, who are already demanding on-the-job training in language and content subjects. This is one of the clear outcomes of the present study and other similar studies previously conducted by Fernández and Halbach (2011).

Both these endeavors require proper research and investigation efforts to ensure relevance of the information gathered so that the recommendations can be communicated to the pertinent authorities.

Another key finding of this study is that it is rather difficult to achieve a statistically valid participation from schools and teachers. Furthermore, the quality of the responses should also be analyzed from a qualitative and quantitative perspective by a professional researcher, as most of the feedback received in the questionnaires is a mixture of emotional and fact-based responses.

Ideally, this initiative should be approached in collaboration with either any professional teaching association or ideally the program staff on the Autonomous Community of Madrid, as a serious attempt to improve the program and as an opportunity to update the contents and to bring the bilingual program up to the highest standards of quality.

As far as the actual logistics of the research are concerned, it would be advisable to hire an external institution or to approach the statistics services department of the community of Madrid to design a survey including elsements such as questionnaires and questions to be sent to the selected centers through the "official" channels. These questionnaires should also be accompanied by an appropriate explanation about the purpose of the research, so that the teachers can see its value and can later participate in focus groups if need be. This survey should also serve as a tool to obtain the experience and thoughts from the most experienced teachers across all the CLIL contents taught in the bilingual 
program. They are key to understanding the specific needs and would additionally provide opportunities to upgrade the bilingual program by incorporating new technologies, methodologies, and contents.

As a final remark on the present study, the feedback obtained from the teachers is consistent with previous studies on this subject and the information gathered regarding their feelings and demands could certainly help to improve the initial and ongoing training objectives and materials. In addition, we hope that our investigation serves as a "heads-up" to the Madrid bilingual program leaders regarding the need to revise the current situation

The main idea that the present research study transpires is that the bilingual program is a strategic initiative in the current academic landscape of the Community of Madrid. Proper preparation of the teachers is the foundation and the key to success; therefore, ensuring adequate attention and continuous focus from the authorities is crucial. This aspect seems to have been addressed correctly at the beginning of the implementation, but real experience shows us that this meticulous approach has decreased over recent years and that a review of the current structure, processes and resources is needed in order to move forward in the years ahead with the highest levels of motivation and quality in teaching.

\section{REFERENCES}

Council of Europe. (2001). Common European framework of reference for languages: Learning, teaching, assessment. Cambridge, UK: Cambridge University Press. Retrieved from http://www.coe.int/t/dg4/linguistic/ Source/Framework_EN.pdf

Council of Europe. (2006). Plurilingual Education in Europe: 50 years of international co-operation. Strasbourg, France: Language Policy Division. Retrieved from http:/www.coe.int/t/dg4/linguistic/source/plurinlingaleducation en.pdf Coyle, D. (2005). CLIL activity in the UK. In H. Krechel (Ed.), Mehrsprachiger Fachunterricht in Landern Europas (p. 23). Tübingen, Germany: Gunter Narr Verlag.

Fernández, R., \& Halbach, A. (2011). Analysing the situation of teachers in the Madrid bilingual project after four years of implementation. In Y. Ruiz de Zarobe, J. Sierra, \& F. Gallardo del Puerto (Eds.), Content and foreign language integrated learning (p. 241-270). Bern, Switzerland: Peter Lang. 
Fernández Fernández, R., Pena Díaz, C., García Gómez, A., \& Halbach, A. (2005). La implantación de proyectos educativos bilingües en la Comunidad de Madrid: Las expectativas del profesorado antes de iniciar el proyecto. Porta Linguarum, 3, 161-173. Retrieved from http://dialnet.unirioja.es/descarga/ articulo/1153792.pdf

Figel, J. (2006). Content and language integrated learning (CLIL) at school in Europe. Brussels, Belgium: Eurydice.

Genesee, F. (1987). Learning through two languages: Studies of immersion and bilingual education. Cambridge, MA: Newbury House.

Johnson, M. (2012). Bilingual degree teachers' beliefs: A case study in a tertiary setting. Pulso, 35, 49-74.

Laorden Gutiérrez, C., \& Peñafiel Pedrosa, E. (2010). Proyectos bilingües en los centros de la Comunidad de Madrid: Percepción de los directivos. Revista de Investigación Educativa, 28(2), 325-326.

Marsh, D. (2000). Using languages to learn and learning to use languages: An introduction to content and language integrated learning for parents and young people. D. Marsh \& G. Langé (Eds.). Jyväskylä, Finland/Milan, Italy: TIE-CLIL, University of Jyväskylä/Ministero della Pubblica Istruzione. Retrieved from http://archive.ecml.at/mtp2/CLILmatrix/pdf/1UK.pdf

Olivares Leyva, M., \& Pena Díaz, C. (2013). How do we teach our CLIL teachers? A case study from Alcalá University. Porta Linguarum, 19, 87-99.

Pena Díaz, C., \& Porto Requejo, M. (2008). Teacher beliefs in a CLIL education project. Porta Linguarum, 10, 151-161.

Tucker, R., \& Earl Lambert, W. (1972). Bilingual education of children: The St. Lambert experiment. TESOL Quarterly, 7(3): 321-325.

\section{APPENDIX 1: TEACHER QUESTIONNAIRE}

\section{Survey about professional teacher-training for the bilingual project in the Autonomous Community of Madrid}

Submission Deadline: October 14th, 2013. This questionnaire is intended for teachers currently working in the Bilingual Project of the Comunidad de Madrid (Autonomous Community of Madrid). The aim is to gather information confidentially about the training that the teachers have already received and the training that they would like to receive or reinforce. 
Should you have any doubts or problems when completing this questionnaire, please do not hesitate to contact with me through by email: cg.pilar@hotmail.com. Thank you in advance for your participation.

\section{General information}

1. Name of the school:*

2. Location of the school (town):*

3. First implementation of the bilingual project (year):*

4. Gender:*

5. Years working as a teacher:*

6. Years working in the bilingual project of the Comunidad de Madrid:*

7. Level of English:*

- Elemental

- Intermediate

- Advanced

- Proficiency

- Other:

8. Specialized in: *

- $\quad$ English language

- Science

- Music

- $\quad$ Arts and crafts

- Physical education

- Other:

Training you have received as a preparation for the bilingual project of the Autonomous Community of Madrid

1. Which courses have you attended in order to improve your initial English Language skills?* (Please tick as many as necessary)

- $\quad$ Courses held by British Council

- Courses held in United Kingdom by British universities and institutions

- $\quad$ Online courses 
- Other:

2. Please select your field of specialization:*

- $\quad$ English language

- Science

- Music

- $\quad$ Arts and Crafts

- Physical Education

- Other:

Now indicate what course or courses you attended and where were they held:*

3. Did you receive other professional training different from the mentioned above?* (Please tick as many as necessary)

- Methodology

- $\quad$ Use of ICT

- Design of materials

- Location of resources

- Other:

\section{Training that you have not initially received or that you would like to reinforce}

1. Which courses would you like to receive in order to reinforce your English language skills?* (Please tick as many as necessary)

- $\quad$ English language courses overseas

- $\quad$ English language courses at academies such as the British Council or Official School of Languages

- $\quad$ Permanent English language courses in the school where you are working in. at your work place

- $\quad$ Online courses

- Intensive courses in "English villages" in Spain

- Other:

2. In which of the following areas regarding your field of specialization would you like to have a further professional training today?* (Please tick as many as necessary)

- $\quad$ Adapting the contents of the subjects 
- $\quad$ Planning the subject or subjects

- Methodology

- Location of resources

- Design of materials

- $\quad$ Use of ICT

- $\quad$ Assessment strategies

- Classroom management and motivation

- $\quad$ Teaching reading and writing skills

- $\quad$ Teaching listening and speaking skills

- $\quad$ Working with mixed-ability levels

- Dealing with grammar, vocabulary and pronunciation

- Other:

Your evaluation on teaching training received so far to perform your profession as a teacher working in the bilingual project

1. In general, are you satisfied with the professional teaching training you have received so far?*

- $\quad$ Yes

- No

- Other:

2. The teaching training you have received in general is:* Please justify your previous answer:*

3. Are you receiving any further training today from the Administration?* If you answered "yes" to the previous question, please indicate what course or courses and the institution providing it.

Course/s and Centre:

4. The teaching training you are receiving today is:

Only answer if it is the case.

Please justify your previous answer:

5. Do you think your training (language level, methodological training, etc.) allows you a good development in of the Project?*

- Yes

- No 
- Other:

Further comments:

\section{APPENDIX 2: RESPONSES ON EVALUATION OF TEACHER TRAINING}

Figure 1 shows responses from the professionals to the second question, included in the final section of the questionnaire: "Your evaluation on teaching training received so far to perform your profession as a teacher working in the bilingual project." Literal sentences from participants are shown.

\begin{tabular}{|c|c|}
\hline $\begin{array}{l}\text { 2. The teaching training you } \\
\text { have received in general is: }\end{array}$ & Please justify your previous answer: \\
\hline Sufficient & I think the university studies are not adequate to the job. \\
\hline Adequate & $\begin{array}{l}\text { The teachers at University were fantastic, and the most important thing to teach in a bilingual school is spending a year teaching in an English } \\
\text { Speaking Country, learning the language and understanding the difficulties of the students with a foreign language. }\end{array}$ \\
\hline Needs improvement & The initial trainig was adequate, but we have not had any futher training. \\
\hline Needs improvement & $\begin{array}{l}\text { It is difficult to answer this question. I am generally satisfied with the training courses I have received, but I have sought them out myself. I have } \\
\text { chosen to continue my training, but this training does not really form part of the "bilingual programme". It is training open to any English teacher } \\
\text { in the CAM. } \\
\text { After I received my "habilitación" (by exam), there were no obligatory training sessions for me to complete. Therefore, in theory, I could now be a } \\
\text { "bilingual teacher" by virtue of my English level alone, without ever needing to receive further training in bilingual teaching methodologies. } \\
\text { While it is true that teachers will always have different classroom techniques, I do think we (bilingual programme teachers) would benefit from } \\
\text { regular "refresher" courses in CLIL methodologies or even basic classroom management techniques, with an aim to bring some homogeneity to } \\
\text { bilingual classrooms. }\end{array}$ \\
\hline Sufficient & $\begin{array}{l}\text { IN GENERAL THE GRADE OF SATISFACTION DEPENDS ON THE COURSE. I DID SOME REALLY GOOD COUSES IN ENGLISH. } \\
\text { ACTUALLY THE WORST COURSES ARE THOSE ABOUT NEW TECHNOLOGIES OR ALSO THOSE COURSES WE DO BY OURSELVES } \\
\text { AT SCHOOL. }\end{array}$ \\
\hline Sufficient & I have a good level of English and I feel I'm a resourceful person, but some others are not in my case. \\
\hline Adequate & $\begin{array}{l}\text { WE WOULD LIKE TO HAVE MORE PERMANENT TRAINING COURSES ABOUT THE BILINGUAL PROJECT IN THE SCHOOL WHERE WE } \\
\text { WORK. }\end{array}$ \\
\hline Sufficient & I think my training should have been more intensive and centred in our job. It was really theoretical. \\
\hline Needs improvement & $\begin{array}{l}\text { I would like to attend more training courses in which I could learn new methods or techniques to be able to adapt myself to the current needs of } \\
\text { my students. I think that it is very important that teachers keep studying to improve and renew their methods. }\end{array}$ \\
\hline Sufficient & It would be excellent to have permanent teaching training in the school where we work. \\
\hline Needs improvement & Not enough practical trainning \\
\hline Needs improvement & Never is enough. English teachers must improve always their teaching training. \\
\hline Needs improvement & Definetely, our teaching training is not enough, we need more viariety of courses and during more time. \\
\hline Sufficient & Depending on the level of conciuousness and proffesionality you have, you will have a better training or not. Our profession is a life-long learning. \\
\hline Insufficient & $\begin{array}{l}\text { Although the level of formation now is much better than before, we need to still improving and keep on changing our minds related with this } \\
\text { topic. }\end{array}$ \\
\hline Adequate & For those teachers who want improve their language skills, there are many opportunities to do it. \\
\hline Sufficient & tend to many courses by my way. \\
\hline
\end{tabular}

Figure 1. Responses from the professionals to question number 2 .

Cabezuelo Gutiérrez, P., \& Fernández Fernández, R. (2014). A case study on teacher training needs in the Madrid bilingual project. Latin American Journal of Content and Language Integrated 


\section{BIODATA}

Pilar Cabezuelo Gutiérrez holds a degree in Primary Teaching from the Centro Universitario Cardenal Cisneros (Alcalá de Henares, Madrid, Spain) and a Master in Teaching English as a Foreign Language (Bilingual Education) from the Universidad de Alcalá (Madrid, Spain).Her training also involved a Practicum period in Ireland. She is currently involved in teaching English to pre-school learners. Her main research areas are teacher training, bilingual education, and CLIL.

Raquel FERNÁNDEZ FERNÁNDEZ works as a University Lecturer at the Centro Universitario Cardenal Cisneros. She has been the coordinator of the Bilingual Project since 2009 and is also the co-director of the Expert in CLIL online postgraduate course. She has been involved in researching bilingual projects in terms of teacher training needs and CLIL implementation since 2004. 